DOI https://doi.org/10.18551/rjoas.2018-06.32

\title{
THE EFFECTS OF TANGIBILITY OF ASSETS AND NON-DEBT TAX SHIELD TOWARD CAPITAL STRUCTURE WITH PROFITABILITY AS INTERVENING VARIABLE OF MANUFACTURING COMPANIES REGISTERED AT INDONESIAN STOCK EXCHANGE
}

\author{
Griska Chikita Tiara*, Student \\ Master's Program of Management, University of Sriwijaya, Indonesia \\ Isnurhadi, Widiyanti Marlina, Lecturers \\ Department of Management, Faculty of Economics, University of Sriwijaya, Indonesia \\ *E-mail: chikitagriska@gmail.com \\ ORCID: 0000-0001-7940-825X
}

\begin{abstract}
This research was aimed to identify the effects of tangibility of assets and non-debt tax shield toward capital structure with profitability as intervening variable of manufacturing companies registered at Indonesian Stock Exchange. The samples of this study were 42 companies in manufacturing sector in the period 2012-2016. Samples were chosen by using simple random sampling method. The data was analyzed by using path analysis with the help of SPSS 23. The results of the research explained; tangibility of assets positively and significantly affected capital structure. Non-debt tax shield and profitability negatively and significantly affected capital structure. Tangibility of assets negatively and significantly affected profitability. Non-debt tax shield did not affect profitability. Profitability mediated tangibility of assets towards capital structure. Profitability was unable to mediate non-debt tax shield towards capital structure.
\end{abstract}

\section{KEY WORDS}

Tangibility of assets, non-debt tax shield, profitability, capital structure.

The development of manufacturing industry has been relatively better nowadays compared to four years ago which only grew approximately $3 \%$. This is supported by the high rate of society consumption, the increase of investment in industrial sector, and the maintenance of performance. When the company intended to increase the company performance, the capital was needed to support both operational and non-operational activities. The fulfillment of the fund for the company might come from inside the company (internal) or outside the company (external). The company needed to consider whether the fund was fulfilled by their own capital, debt, or the combination of those two. This consideration was identified as capital structure. According to Brigham and Houston (2014), a developing company needed a capital which was originated from debt and equity.

Capital structure was an essential matter for the company since it became the representation of financial state of the company. The fineness state of the capital structure would give direct impact to the financial position of the company. The height rate of the capital structure would surely affect investors' decision when they intended to invest the capital to a company. Besides, the financial state of the company could affect the consideration of the investors, whether the company's policy which was handled by the finance manager could provide affluence for the stockholders.

There were many factors that affect capital structure, such as tangibility of assets, nondebt tax shield, and profitability. Tangibility of assets described some assets which could be collateral value of assets. Based on trade-off theory, when the company needed an addition of capital, it also needed tangible assets to offer collateral to the creditors. Brigham and Gapenski (2006) stated that generally, the company which had collateral for the debt would be easier to receive debt than the company which did not have any collateral. The company 
whose assets were suitable for the collateral credit tended to use more debt. There were a lot of researches that discussed tangibility of assets toward capital structure. A research by Biorck and Lagercrantz (2011), Chen (2013) presented that tangibility of assets positively and significantly affected the capital structure. It was different from a research by Rizky et al., (2016) which showed that tangibility of assets negatively affected the capital structure. Meanwhile, Thippayana (2014) stated that tangibility of assets had no impact to the capital structure.

The company that had big taxes charges would find a method to reduce those taxes charges. The method which could be utilized to reduce the taxes was by a tax shield. Debt charges could be utilized as a tax shield since the interest could reduce income tax (Van and Wachowicz, 1998). Trade-off theory stated that the company which had to pay00 high taxes should use more debt that the company which had to pay low taxes. The company which had high non-debt tax shield did not need to use high amount of debt (Sari, et al., 2013). This was because the depreciation charges could be utilized as a substitute for tax shield which was originated from debt interest charges, so that the company did not need to use more debt to receive the tax shield.

The result of empirical research on the effect of non-debt tax shield towards the capital structure was still inconsistent. Non-debt tax shield which affected the capital structure could be seen from research by Sari et al. (2013) and Sundari and Susilowibowo (2016). Biorck and Lagercrantz (2011), Lim (2012) and Krisnanda and Wikusuana (2015) on their research, meanwhile, concluded that non-debt tax shield positively and significantly affected capital structure.

The result of the investigation on empirical study of tangibility of assets and non-debt tax shield was still inconsistent, so that there was a gap which could be done by putting profitability variable as intervening variable with a pattern that high profitability would affect the use of relatively low debt. This was occurred since the company utilized retained profit or internal fund to support their operational activities.

According to the explanation above, the research problems included: 1) how did tangibility of assets and non-debt tax shield directly affect capital structure? 2) how did tangibility of assets and non-debt tax shield affect capital structure with profitability as an intervening variable?. The objectives of the research were: 1) to identify and analyze the direct effects of capital structure and non-debt tax shield toward capital structure in manufacturing companies which were registered at BEI in $2012-2016$. 2) to identify and analyze the effects of capital structure and non-debt tax shield toward capital structure with profitability as an intervening variable in manufacturing companies which were registered at $\mathrm{BEI}$ in $2012-2016$.

\section{CONCEPTUAL AND HYPOTHETICAL FRAMEWORK}

The objective of capital structure management was to determine the sources of the fund which were utilized by the company for its operation that would maximize the value of the company. The manager of the company had to choose an appropriate costing alternative to provide optimum result for the company and the owner. The objective of the research was to identify the effects of tangibility of assets and non-debt tax shield toward capital structure with profitability as intervening variable. Some utilized variables included capital structure which was correlated to tangibility of assets (TOA) and non-debt tax shield (NDTS) as independent variables, profitability which was correlated to return on assets (ROA) as intervening variables, and capital structure which was correlated to debt to equity ratio (DER) as dependent variables. 


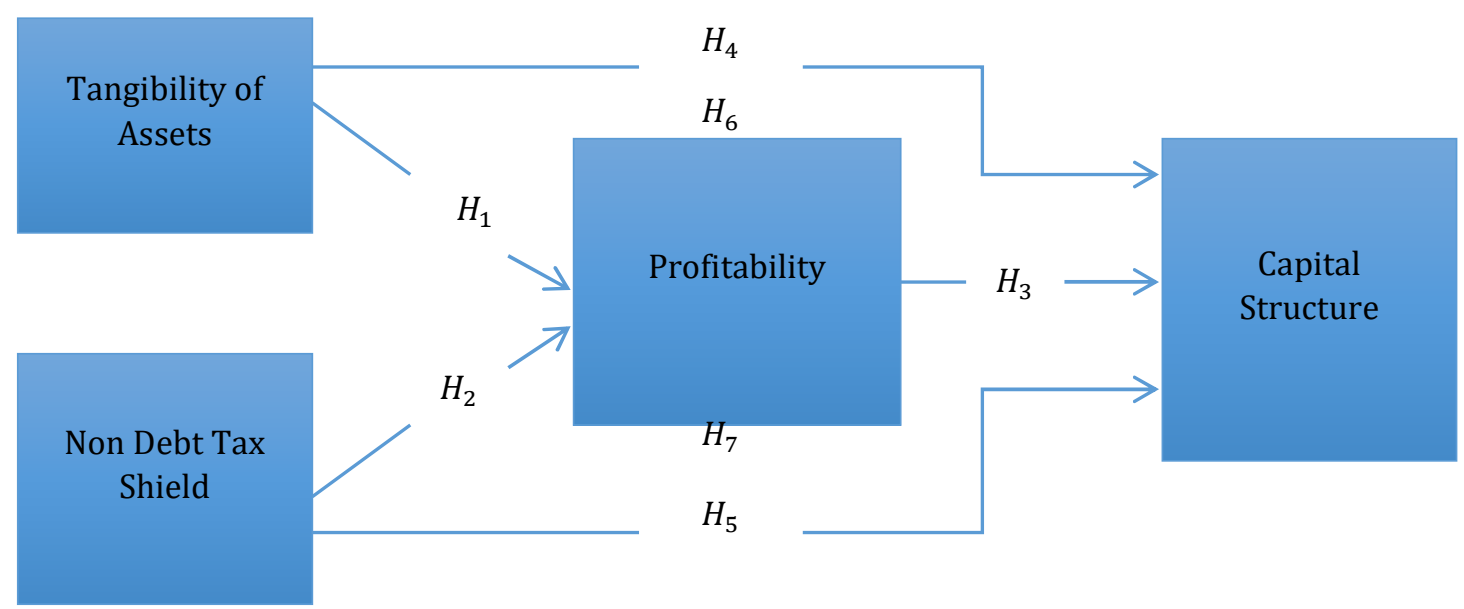

Figure 1 - Hypothetical Model of the Research

Hypotheses:

$\mathrm{H}_{1}=$ Tangibility of assets positively and significantly affected capital structure;

$\mathrm{H}_{2}=$ Non-debt tax shield negatively and significantly affected capital structure;

$\mathrm{H}_{3}=$ Profitability negatively and significantly affected capital structure;

$\mathrm{H}_{4}=$ Tangibility of assets negatively and significantly affected profitability;

$\mathrm{H}_{5}=$ Non-debt tax shield positively and significantly affected profitability;

$\mathrm{H}_{6}=$ Profitability mediated tangibility of assets towards capital structure;

$\mathrm{H}_{7}=$ Profitability mediated non-debt tax shield towards capital structure.

\section{METHODS OF RESEARCH}

The populations in this research consisted of 150 manufacturing companies registered at Bursa Efek Indonesia (BEI) based on the publication of Indonesian Capital Market Directory (ICMD) in the period of 2012 to 2016.

The sampling technique utilized in the research was in the form of probability sampling by simple random sampling. It was called as simple since the sample members from the populations were chosen randomly without paying attention to the stratum in that population (Sugiyono, 2014). The sampling technique in this research was carried out by choosing the companies randomly from the list of 42 manufacturing companies registered at Bursa Efek Indonesia (BEI) in 2012 - 2016 with the number of observation about 210 companies (42 companies, 5 years).

Table 1 - Operational Definition

\begin{tabular}{|c|c|c|c|c|}
\hline No & Variable & Definition of Variable & Formula & $\begin{array}{c}\text { Scale of } \\
\text { Measurement }\end{array}$ \\
\hline \multirow[t]{2}{*}{1} & \multirow{2}{*}{$\begin{array}{l}\text { Tangibility of Assets } \\
\text { (TOA) }\end{array}$} & \multirow{2}{*}{$\begin{array}{l}\text { Comparative ratio between fixed assets } \\
\text { and current assets }\end{array}$} & Fixed Assets & Ratio \\
\hline & & & $\overline{\text { Total Assets }}$ & \\
\hline \multirow[t]{2}{*}{2} & \multirow{2}{*}{$\begin{array}{l}\text { Non Debt Tax } \\
\text { Shield (NDTS) }\end{array}$} & \multirow{2}{*}{$\begin{array}{l}\text { Measurement ratio of the reduction of } \\
\text { taxes except reduction of debt }\end{array}$} & Depreciation + Amortization & Ratio \\
\hline & & & Total Assets & \\
\hline \multirow[t]{2}{*}{3} & \multirow{2}{*}{$\begin{array}{l}\text { Return on Assets } \\
\text { (ROA) }\end{array}$} & \multirow{2}{*}{$\begin{array}{l}\text { The ration which measures return rate of } \\
\text { the assets }\end{array}$} & Nett Profits & Ratio \\
\hline & & & $\overline{\text { Total Assets }}$ & \\
\hline \multirow[t]{2}{*}{4} & \multirow{2}{*}{$\begin{array}{l}\text { Debt to Equity Ratio } \\
\text { (DER) }\end{array}$} & \multirow{2}{*}{$\begin{array}{l}\text { Comparative ratio between total debt and } \\
\text { total capital (Hamidy, }\end{array}$} & Total Debt & Ratio \\
\hline & & & $\overline{\text { Total Equity }}$ & \\
\hline
\end{tabular}

Source: adapted from various journals.

The data in this research was secondary data in the form of financial report of the company in the period of 2012 to 2016.

The method of data collection was documentation, in which the data was collected from the annual financial report of the companies and annual report of the companies in the period of five year from 2012 to 2016 . The method was carried out by listing the whole data needed 
in the research to calculate tangibility of assets, non-debt tax shield, return on assets, and debt to equity ratio which later to be analyzed.

Operational definition of the research variables was the explanation of each variable in the research towards their indicators. The operational definition could be seen in Table 1.

This research provided average statistics which was equipped by the highest and the lowest score on each variable of investment decision, risks factors, liquidity ratio, and company value.

Inferential statistics used in this research was in the form of path analysis. It was a technique of extension or development from double linier regression analysis. Statistical Product and Service Solution (SPSS) verse 23 was utilized as an application to analyze the data.

\section{RESULTS AND DISCUSSION}

Descriptive Statistics:

Table 2 - The Result of Descriptive Statistics

\begin{tabular}{llllll}
\hline & $\mathrm{N}$ & Minimum & Maximum & Mean & Std. Deviation \\
\hline TOA & 210 & .03 & .86 & .3790 & .20181 \\
NDTS & 210 & .01 & .52 & .2076 & .11303 \\
ROA & 210 & -7.71 & 19.69 & 5.8565 & 5.93057 \\
DER & 210 & .04 & 1.64 & .6771 & .37107 \\
Valid N & 210 & - & - & - & - \\
\hline
\end{tabular}

Source: Researcher's data.

The result of research variable statistics description could be seen from Table 2 above. The lowest TOA value (minimum) was 0.03 by PT Jaya Pari Steel (Persero) Tbk while PT Holcim Indonesia Tbk had the highest value (maximum) 0.86 . The mean of TOA variable was 0.3790 with lower standard deviation 0.20181 described that there was small fluctuation of TOA. Table 2 presented the lowest score of NDTS 0.01 which was held by PT Indospring Tbk, while the highest value 0.52 was PT Keramika Indonesia Assosiasi Tbk. The mean of NDTS variable was 0.2076 higher than the standard deviation 0.11303 in which showed that the fluctuation of NDTS was small.

The value of ROA variable from the entire sample during the observation was the lowest (minimum) -7.71 by PT Keramika Indonesia Assosiasi Tbk while the highest score (maximum) was 19.69 by PT Lion Mrtal Works Tbk. The mean of ROA was 5.8565 with standard deviation 5.93057. The lower mean than the standard deviation indicated that there was high fluctuation in the company which was chosen as a sample.

The capital structure which was represented by proxy Debt to Equity Ratio (DER) had the lowest value (minimum) 0.04 by PT Jaya Pari Steel (Persero) Tbk while PT Indofarma (Persero) Tbk had the highest value (maximum) 1.64 from the sample and the set time of the research. The mean of DER was 0.9278 which was higher than the standard deviation 0.57098 so that the fluctuation of the capital structure of the company was small. This could be indicated from the standard deviation of the capital structure which was lower from its mean.

Inferential Statistics. Linearity test was carried out to identify whether the model was accurate to explain the relationship between variables being observed and was considered as a good model. One of the assumptions in regression was that the relationship between dependent variables and independent variables was linear.

Table 3 - The Result of Variables Linearity Test

\begin{tabular}{|c|c|c|c|c|}
\hline Independent Variable & Dependent Variable & Test Result $(\alpha=0.05)$ & Sig. & Decision \\
\hline TOA & ROA & All models were significant & 0,000 & Linear \\
\hline NDTS & ROA & All models were not significant & 0,387 & Linear \\
\hline TOA & DER & All models were significant & 0,000 & Linear \\
\hline NDTS & DER & All models were not significant & 0,070 & Linear \\
\hline ROA & DER & All models were significant & 0,000 & Linear \\
\hline
\end{tabular}


Curve Fit approach was utilized in which the rules of decision referred to parsimony concept, when the entire models as the basis of the test were significant or not significant, or the linear function was significant so that the model was considered as linear. Table 3 presented that all forms of relationships between variables in the structural model were linear. Therefore, the linearity assumption in this structural model was fulfilled.

The test result of the goodness of fit model could be fulfilled if it was supported by a valid data calculation. Goodness of fit structural model analyzed was the total determination coefficient value $\left(R_{m}^{2}\right)$. This value was calculated based on $R^{2}$ value of each dependent variable. According to those $R^{2}$, the value of predictive relevance $\left(Q^{2}\right)$ was 0.632 in which the model utilized to predict dependent variable was worth to test the hypothesis. The value of total determination coefficient was $63.2 \%$ which meant that it was good and accurate value to predict corporate obligation value, the remaining $36.8 \%$ was not included in this research.

Table 4 - R Square value of Dependent Variable

\begin{tabular}{ll}
\hline Dependent Variable & R square \\
\hline DER & 0,421 \\
ROA & 0,365 \\
Predictive-relevance $\left(Q^{2}\right)$ & 0,632 \\
\hline
\end{tabular}

The Result of Hypothesis Testing. Direct testing was carried out to identify the effect of investment decision towards the value of the company. The basis of the hypothesis used $p$ value $5 \%$. If $p$ value was lower than $5 \%$ it indicated that the hypothesis was significant, on the other hand, if $\mathrm{p}$ value was greater than $5 \%$, the hypothesis was considered not significant. The result of the testing could be seen in Table 5:

Table 5 - Test Result of the Direct Effect

\begin{tabular}{llll}
\hline Independent Variable & Dependent Variable & Path Coefficient & $p$-value \\
\hline TOA & DER & 0,356 & 0,000 \\
NDTS & DER & $-0,199$ & Significant \\
ROA & DER & $-0,305$ & 0,003 \\
Significant & 0,000 \\
\hline
\end{tabular}

The analysis of tangibility of assets (TOA) towards capital structure (DER) resulted path coefficient value 0.038 with positive significance level 0.000 . Hypothesis $1\left(H_{1}\right)$ which stated that tangibility of assets positively and significantly affected the capital structure was accepted. The significance level of the effect of non-debt tax shield (NDTS) towards capital structure (DER) was 0.003 with path coefficient value -0.915 . Hypothesis $2\left(\mathrm{H}_{2}\right)$ which stated that non-debt tax shield negatively and significantly affected the capital structure was accepted. The effect of profitability variable (ROA) towards capital structure variable (DER) resulted path coefficient value -0.216 with negative significance level 0.002 . Hypothesis 3 $\left(\mathrm{H}_{3}\right)$ which stated that profitability negatively and significantly affected the capital structure was accepted.

The test on the effects of mediation variable or the test on the indirect effects was aimed to identify the position of mediation variable in this research: profitability. The examination process towards profitability variable to determine the type of mediation whether it was partial mediation or complete mediation could be carried out by (1) Calculating path coefficient by including profitability variable in the empirical model and (2) Calculating $p$ value by using sobel test. The result of these two methods explained in Table 6.

The analysis of tangibility of assets (TOA) variable towards profitability variable (ROA) resulted path coefficient value -0.368 with negative significance level 0.000 . This indicated that tangibility of assets (TOA) moved in reverse with the profitability (ROA). Hypothesis 4 $\left(\mathrm{H}_{4}\right)$ which stated that tangibility of assets negatively and significantly affected profitability was accepted.

The significance value of the effects of non-debt tax shield (NDTS) variable towards profitability (ROA) resulted path coefficient 0.016 with positive significance level 0.812 . This indicated that non-debt tax shield (NDTS) was not significantly affected profitability (ROA). 
Hypothesis $5\left(\mathrm{H}_{5}\right)$ which stated that non-debt tax shield positively and significantly affected profitability was declined.

Table 6 - The Result of Mediation Variable Testing

\begin{tabular}{lllllll}
\hline $\begin{array}{l}\text { Independent } \\
\text { Variable }\end{array}$ & $\begin{array}{l}\text { Intervening } \\
\text { Variable }\end{array}$ & $\begin{array}{l}\text { Dependent } \\
\text { Variable }\end{array}$ & $\begin{array}{l}\text { Path } \\
\text { Coefficient }\end{array}$ & $p$-value & Sobel Test & Information \\
\hline TOA & & ROA & $-0,368$ & 0,000 & & Significant \\
NDTS & & ROA & 0,016 & 0,812 & & Not significant \\
TOA & ROA & DER & 0,112 & 0,000 & 3,550 & Mediating \\
NDTS & ROA & DER & $-0,004$ & 0,812 & 0,2337 & Not mediating \\
\hline
\end{tabular}

The result of the calculation described that total effect coefficient $(0.468)$ was higher than indirect effect $(0.112)$ and direct effect $(0.356)$. This indicated that there was a probability of partial mediation by referring to sobel statistics value and its significance level. The result of sobel statistics was 3.550 with $p$ value $0.000<0.05$ so that it could be summarized that sobel statistics was significant. In conclusion, profitability had the role as an intervening variable in the form of partial mediation. Hypothesis $6\left(\mathrm{H}_{6}\right)$ which stated that profitability mediated tangibility of assets towards capital structure was accepted.

The result of the calculation stated that total effect coefficient $(-0.2013)$ was lower than indirect effect $(-0.004)$ and direct effect $(-0.199)$. This indicated that there was a possibility that mediation did not occur. The result of sobel statistics was 0.237 with $p$ value $0.812>$ 0.05 so it could be concluded that sobel statistics was not significant. Hypothesis $7\left(\mathrm{H}_{7}\right)$ which stated that profitability mediated non-debt tax shield was declined.

The high tangibility of assets described that the company was at the ease to receive debt. Fixed assets owned by the company could be designated as a collateral for the creditor to receive agreement for the debt. The higher the tangibility of assets, the higher the capability of the company to receive debt collateral for a long period of time.

The company with high tangibility of assets tended to use fund from external parties or from debt to support their capital needs since a big-scale company had more capability and flexibility to access external sources of fund so that it was likely to increase the debt. This was occurred because the creditor was more interested in the big company than the small company since the debt from creditor required a decent collateral as much as the amount which was lent to the company. The company which had greater assets tended to face lower risk of bankruptcy than the company which had smaller assets (Dewi, 2016). The result of the research identified that tangibility of assets positively and significantly affected capital structure so that the increase of tangibility of assets was followed by the increase of capital structure.

The research findings explained that non-debt tax shield negatively and significantly affected capital structure. When the company had high non-debt tax shield it could affect the decrease on capital structure. The company which had high non-debt tax shield did not required to use high amount of debt. This was because the depreciation charges could be utilized as tax shield substitution which came from debt charges so that the company no longer required to use a lot of debt to obtain tax shield.

The company which had high taxes charges would seek for a method to reduce the charges. The method that could be used was by tax shield, however, by the existence of non-debt tax shield, the company no longer used tax shield to reduce taxes charges. Nondebt tax shield determined the capital which did not come from debt, on the other hand, they came from depreciation cost and amortization towards profit and loss.

The company with high capability to earn profits would utilized retained profits (their own capital) as the capital to support their operational activities without spending the fund from outside of the company (Stella, 2015). Retained profits was utilized support their operational activities so that the company would not require some amount of fund from external parties. The use of retained profits or their own capital would affect capital structure to be smaller. This was in line with the pecking order theory (Myers and Majluf, 1984) which 
explained that the company with high profitability tended to have low debt, since they had abundant internal fund resources.

Investment for fixed assets expected for an optimal return of the invested capital. For the company, fixed assets were the power to acquire optimal return. The proportion of fixed assets which is bigger than the current assets would affect the return rate. Nichols and Buerger (2002) claimed that if the company had too many fixed assets, the interest charges would be too high and would result very low profits. The research findings stated that there were negative and significant effects between tangibility of assets and profitability. If tangibility of assets was higher, the profitability would be lower.

Myers and Majluf (1984) stated that the company with high non-debt tax shield would lower the debt rate if the profits of the company did not increase. This was due to non-debt tax shield as internal fund resources for the company. According to the research findings, non-debt tax shield did not significantly affect profitability. It showed that depreciation charge of the assets could replace debt charges to reduce the tax charges.

Tangibility of assets indicated the ratio between fixed assets with total assets owned by the company which determine the fund allocation for each component of the assets. The higher tangibility assets, the higher the capability of the company to receive debt collateral for a long period of time. The company with high tangibility of assets tended to use the fund from external parties or from the debt to support their capital needs while the big-scale company had more capability and flexibility to access external resources so that it resulted the increase of the debt. This was occurred since the creditors would be more interested in the big-scale companies rather than smaller companies because the debt from the creditors required decent collateral as much as the amount of the debt.

The research findings stated that the profitability partially mediated tangibility of assets towards capital structure. This explained that the profitability made the effects of tangibility of assets became stronger so that the company tended to use more external funds for their operational activities. According to this assumption, the profits obtained by the company would not be retained since the company used debt as their resource. The profits would be distributed to the stockholders through dividend. As a result, if the dividend was continuously distributed, the company would gain more value from the investors.

Armstrong et al. (2012) explained that the reduction of the tax from the depreciation would substitute the benefits of the tax from credit finance so that the company with high non-debt tax shield would use small amount of debt. The company which used small amount of debt would use retained profits or internal fund as their finance resource. It indicated that the profits of the company were high.

The research findings described that profitability could not be mediation variable between non-debt tax shield and capital structure. It was assumed that the company preferred external funding than internal funding. The company was more focused on the assets of the company to assure the creditors for the debt of the company. The profits of the company would be a dividend so that investors would be attracted to invest their capital to the company.

\section{CONCLUSION AND SUGGESTIONS}

The followings were the conclusions of the research:

- Tangibility of assets positively and significantly affected capital structure;

- Non-debt tax shield negatively and significantly affected capital structure;

- Profitability negatively and significantly affected capital structure;

- Tangibility of assets negatively and significantly affected profitability;

- Non-debt tax shield did not significantly affected profitability;

- Profitability mediated tangibility of assets variable towards capital structure variable;

- Profitability could not mediate non-debt tax shield variable towards capital structure variable. 


\section{Suggestions:}

- The company should be more thorough in determining the value of fixed assets, because if the fixed assets exceed its portion, it results low profits. However, if the company has low assets, they would not have any collateral to acquire debt from the creditors.

- The management officials should be able to maintain the stability of the profits, increase financial performance and the value of the company for the existence and good prospect of the company in the future.

- The investors are supposed to be more careful in making the decision of investment to manufacturing sectors. The investors should be able to explore and examine the information of tangibility of assets owned by the company so that they could identify whether the company utilizes internal or external funding to support operational activities of the company.

\section{REFERENCES}

1. Armstrong, C. S., Blouin, J. L., \& Larcker, D. F. (2012). The incentives for tax planning. Journal of Accounting and Economics, 53(1-2), 391-411.

2. Biorck, J., \& Lagercrantz. (2011). The Determinants of Capital Structure An Empirical Study of Differences between Swedish SMEs and Large Companies. Stockholm School of Economics, (July), 1-29.

3. Brigham, E. F. and F. J. Houston. (2014). Dasar-Dasar Manajemen Keuangan, Edisi Kesebelas. Edisi Indonesia. Jakarta: Salemba Empat.

4. Brigham, E.F. dan L. C. Gapenski. (2006). Intermediate Financial Management. 7th edition. Sea Harbor Drive: The Dryden Press, New York.

5. Chen, Z. Q. (2013). The Determinants of Capital Structure of Companies in Japan. The University of Nottingham.

6. Dewi, C. N. M. (2016). Pengaruh Leverage , Ukuran Perusahaan , Dan Non Debt Tax Shield Pada Kinerja Kuangan. Jurnal IImu Dan Riset Manajemen, 3(1), 142-160.

7. Krisnanda, P.H. (2015). Pengaruh Ukuran Perusahaan, Pertumbuhan Penjualan, Dan Non-Debt Tax Shield Terhadap Struktur Modal Pada Perusahaan Telekomunikasi Di Bursa Efek Indonesia. E-Jurnal Manajemen Universitas Udayana, 4(5), 1434-1451.

8. Lim, T. C. (2012). Determinants of Capital Structure Empirical Evidence from Financial Services Listed Companies in China. Int. J. of Economics and Finance, 4(3), 191-203.

9. Myers, S.C. (1984). Corporate financing and investment decisions when companies have information those investors do not have. Journal of Financial Economics, 13(2), 187-221.

10. Nichols, L. M., \& Buerger, K. H. (2002). An investigation of the effect of valuation alternatives for fixed assets on the decisions of statement users in the United States and Germany. Journal of International Accounting, Auditing and Taxation, 11(2), 155-163.

11. Rizky, M. (2016). Pengaruh Struktur Aktiva, Profitabilitas, dan Pertumbuhan Penjualan Terhadap Struktur Modal (Studi pada Perusahaan Telekomunikasi yang Terdaftar di Bursa Efek Indonesia 2011-2015). E-Proceeding of Management, 3(3), 3249-3256.

12. Sari, M. D. (2015). Pengaruh Profitabilitas, Ukuran Perusahaan, Pertumbuhan Penjualan, Struktur Aset, Non-Debt Tax Shield Dan Usia Perusahaan Terhadap Struktur Modal (Studi Pada Perusahaan Makanan Dan Minuman Di BEI). J. Ekon. Bisnis, 20(1), 1-52.

13. Stella. (2015). Pengaruh Profitabilitas, Non-Debt Tax Shield dan Karakteristik Perusahaan Terhadap Struktur Modal. Jurnal Bisnis Dan Akutansi, 17(1), 96-101.

14. Sugiyono. Metode Penelitian Pendidikan Pendekatan Kuantitatif. (2014). Bandung.

15. Sundari, D., \& Susilowibowo, J. (2016). Pengaruh Ukuran Perusahaan dan Non-Debt Tax Shield Terhadap Struktur Modal Melalui Profitabilitas Sebagai Variabel Intervening Pada Perusahaan Sektor Keuangan. Jurnal IImu Manajemen, 1(1), 1-12.

16. Thippayana, P. (2014). Determinants of Capital Structure in Thailand. Procedia - Social and Behavioral Sciences, 143, 1074-1077.

17. Van, H.J.C. (2012). Pronsip-prinsip Manajemen Keuangan (Edisi 13). Salemba Empat.

18. Weston, J. (2000). Fred, and Brigham, Eugene F. Managerial Finance, 20-21. 